
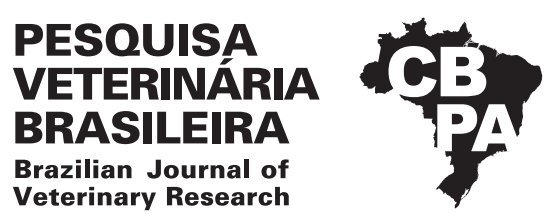

Pesq. Vet. Bras. 38(10):1913-1917, outubro 2018 DOI: 10.1590/1678-5150-PVB-5840

Original Article

ISSN 0100-736X (Print)

ISSN 1678-5150 (Online)

\title{
Evaluation of resistance to natural poisoning by Amorimia septentrionalis in goats which had received sodium monofluoroacetate degrading bacteria ${ }^{1}$
}

\author{
Danielle A.N. Pessoa ${ }^{2 *}$, Layze C.A. Silva ${ }^{3}$, Fábio S. Mendonça ${ }^{4}$, Valdir M. Almeida ${ }^{4}$, \\ José R.G. Lopes ${ }^{2}$, Laio G. Albuquerque ${ }^{2}$, Amanda A. Silva ${ }^{2}$ \\ and Franklin Riet-Correa ${ }^{2,5}$
}

\begin{abstract}
Pessoa D.A.N., Silva L.C.A., Mendonça F.S., Almeida V.M., Lopes J.R.G., Albuquerque L.G., Silva A.A. \& Riet-Correa F. Evaluation of resistance to natural poisoning by Amorimia septentrionalis in goats which had received sodium monofluoroacetate degrading bacteria. Pesquisa Veterinária Brasileira 38(10):1913-1917. Unidade Acadêmica de Medicina Veterinária, Centro de Saúde e Tecnologia Rural, Universidade Federal de Campina Grande, Avenida Universitária s/n, Bairro Santa Cecília, Patos, PB 58700-970, Brazil. E-mail: danipessoavet14@gmail.com

Amorimia septentrionalis is an important sodium monofluoroacetate (MFA) containing plant that causes sudden death in ruminants in northeastern Brazil. MFA degrading bacteria are being used in the prevention against poisoning by this plant. The aim of this study was to evaluate if goats which had per os received MFA degrading bacteria remained resistant when exposed to natural poisoning by A. septentrionalis. Eighteen goats were randomly distributed into three groups: the goats of Group 1 previously received, during 40 days, a solution containing the bacteria Ralstonia sp. and Burkholderia sp., those goats in the Group 2 received the bacteria Paenibacillus sp. and Cupriavidus sp. and goats from Group 3 did not receive any bacteria. After the administration period, during 60 days, the animals of all groups were released to graze on a one hectare paddock, with significant amount of A. septentrionalis. They were observed daily for the spontaneous consumption of A. septentrionalis leaves and the occurrence of clinical signs of poisoning or sudden death. Goats from all groups consumed significant amounts of $A$. septentrionalis during the experimental period. Goats that did not receive MFA-degrading bacteria (Group 3) became sick and died from the 25th to the 27th day of the experiment, whereas the goats of the groups that received MFA-degrading bacteria showed only clinical sings when $A$. septentrionalis regrowth after the 55th day of the experiment. The days elapsed from field observation to death of Group 3 goats $(25.5 \pm 0.9$ days) were significantly lower $(\mathrm{p}<0.05)$ than Group 1 ( $58.6 \pm 1.3$ days) and Group 2 (57.8 \pm 1.5 days). Thus, it can be concluded that administration of MFA degrading bacteria increases the resistance to natural poisoning by A. septentrionalis.
\end{abstract}

INDEX TERMS: Natural poisoning, Amorimia septentrionalis, goats, sodium monofluoroacetate, degrading bacteria, resistence, MFA, toxicoses.

\footnotetext{
${ }^{1}$ Received on June 5, 2018.

Accepted for publication on June 13, 2018.

${ }^{2}$ Unidade Acadêmica de Medicina Veterinária (UAMV), Centro de Saúde e Tecnologia Rural (CSTR), Universidade Federal de Campina Grande (UFCG), Avenida Universitária s/n, Bairro Santa Cecília, Patos, PB 58700-970, Brazil. *Corresponding author: danipessoavet14@gmail.com

${ }^{3}$ Universidade Federal do Oeste da Bahia (UFOB), Avenida 23 de Agosto s/n, Bairro Assunção, Barra, BA 47100-000, Brazil.
}

\footnotetext{
${ }^{4}$ Laboratório de Diagnóstico Animal, Departamento de Morfologia e Fisiologia Animal, Universidade Federal Rural de Pernambuco (UFRPE), Dois Irmãos, Recife, PE 52171-900, Brazil.

${ }^{5}$ Instituto Nacional de Investigación Agropecuaria (INIA), Plataforma de Salud Animal, Estación Experimental INIA La Estanzuela, Ruta 50 Km 11, 39173, Colonia, Uruguay.
} 
RESUMO.- [Avaliação da resistência à intoxicação natural por Amorimia septentrionalis em caprinos que receberam bactérias degradadoras de monofluoroacetato de sódio.] Amorimia septentrionalis que contém monofluoroacetato de sódio (MFA) é responsável pela ocorrência de mortes súbitas em ruminantes no nordeste do Brasil. Bactérias degradadoras desse composto estão sendo utilizadas na prevenção contra a intoxicação por essa planta. 0 objetivo deste estudo foi avaliar se caprinos que receberam, via oral, bactérias degradadoras de MFA permaneciam resistentes quando expostos a intoxicação natural por A. septentrionalis. Dezoito caprinos foram divididos em três grupos, os caprinos do Grupo 1 receberam anteriormente, durante 40 dias, uma solução contendo as bactérias Ralstonia sp. e Burkholderia sp., os do Grupo 2 receberam, também por 40 dias as bactérias Paenibacillus sp. e Cupriavidus sp. e os do Grupo 3 não receberam nenhuma bactéria. Após o período de administração, durante 60 dias, os animais de todos os grupos foram soltos para pastar em um piquete de um hectare, que apresentava uma quantidade significativa da planta. Diariamente eles foram observados quanto ao consumo espontâneo das folhas de $A$. septentrionalis e quanto à presença de sinais clínicos de intoxicação ou morte. Os caprinos de todos os grupos consumiram quantidades significantes da planta durante o período experimental. Os caprinos que não receberam as bactérias degradantes de MFA (Grupo 3) adoeceram e morreram entre o $25^{\circ}$ e o $27^{\circ}$ dia de experimento, enquanto que os que receberam as bactérias degradantes de MFA (Grupo 1 e 2) só apresentaram sinais clínicos no 55으 dia de experimento, o que coincidiu com a rebrota da planta. Os dias transcorridos desde a observação a campo até a morte dos caprinos do Grupo 3 $(25,5 \pm 0,9$ dias $)$ foram significativamente menores $(\mathrm{p}<0,05)$ que os do Grupo 1 (58,6 $\pm 1,3$ dias) e do Grupo 2 (57,8 $\pm 1,5$ dias). Com isso pode-se concluir que a administração de bactérias degradadoras de MFA aumenta à resistência a intoxicação natural por A. septentrionalis.

TERMOS DE INDEXAÇÃO: Amorimia septentrionalis, resistência, monofluoroacetato de sódio, bactérias degradadoras de MFA, caprinos, bacterioses, toxicoses.

\section{INTRODUCTION}

The poisoning of production animals by toxic plants cause a negative impact in the Brazilian livestock. It is estimated that annually $50 \%$ of the bovine deaths caused by toxic plants are from plants that cause sudden death associated to the exercise, being the plants of the Amorimia spp. genus the most important in the Northeast region (Pessoa et al. 2013).

Amorimia septentrionalis, previously identified as Amorimia (Mascagnia) rigida, popularly known as tingui (Duarte etal. 2014), has as toxic principle sodium monofluoroacetate (MFA) (Lee et al. 2012). This compound acts on the tricarboxylic acid cycle, causing accumulation of citrate and lactate, decrease in the blood $\mathrm{pH}$ and depletion of cellular energy. The circulating citrate accumulates in all tissues, mainly in the myocardium, where it blocks the metabolic processes dependent on energy, causing the death of the animal (Nogueira et al. 2010).

The control and prophylaxis of this poisoning by traditional methods such as fencing infested areas or using herbicides is not efficient (Barbosa et al. 2003). Therefore, some studies have already used several alternatives to render ruminants resistant to plant poisoning containing MFA, including: 1) the repeated administration of non-toxic doses of the plant containing MFA for alternate periods (Duarte et al. 2014); 2) the transfer of ruminal fluid from ruminants inoculated with MFA-degrading bacteria, which became resistant to poisoning, to susceptible ruminants (Silva et al. 2015); 3) the administration of MFA-degrading bacteria isolated from the rumen of animals, soil and plants containing MFA (Pessoa et al. 2015, Silva et al. 2016); 4) use of the conditioned aversion technique through the use of lithium chloride (Brito et al. 2016).

MFA degrading bacteria, identified as Paenibacillus sp. (ECPB01), Burkholderia sp. (ECPB02), Cupriavidus sp. (ECPB03) and Ralstonia sp. (ECPB06), were isolated from soil and plants containing this compound (Camboim et al. 2012). These bacteria produce dehalogenase enzymes, which catalyze the cleavage of the strong carbon-fluorine bond present in the MFA, degrading and deactivating this compound (Fetzner \& Lingens 1994).

In an earlier study it was shown that goats that received MFA-hydrolyzing bacteria are resistant to poisoning, but after the goats fail to receive the bacteria they gradually lose resistance (Pessoa et al. 2015). On the other hand, if some of these bacteria (Ralstonia sp. and Burkholderia sp.) are continuously administered together with the plant there is no loss of resistance (Silva et al. 2016). The aim of this study was to evaluate whether the resistance to poisoning induced by bacteria that hydrolyze MFA remains when experimentally resistant animals are exposed to natural poisoning by the plant on an ongoing basis. Thus, caprine that had been induced resistance to MFA by oral administration of bacteria that hydrolyze this substance (Silva et al. 2016).

\section{MATERIALS AND METHODS}

The field resistance test was carried out in the municipality of Limoeiro (754'01.8” S - 35²8'38.2” W), in the state of Pernambuco, during the dry season. For this, three groups were used, with six crossbred goats each, with age ranging from one to three years, weighing $20-40 \mathrm{~kg}$. The bacteria used in the present study were isolated from soil and from plants containing sodium monofluoroacetate (MFA) and identified as degrading this substance (Camboim et al. 2012). These were diluted in $0.9 \%$ sodium chloride solution at concentration 1 of the MacFarland scale and the dose used for oral administration in goats was $60 \mathrm{~mL}$ (Silva et al. 2016). The caprine from Group 1 had previously received daily, for 40 days, the solution containing the bacteria Ralstonia sp. and Burkholderia sp., and since the 10th day until the 40 th day, they also received $5 \mathrm{~g} / \mathrm{kg}$ of Amorimia septentrionalis leaves. Caprine from Group 2 received for 40 days the solution containing the bacteria Paenibacillus sp. and Cupriavidus sp., and since the 10th day until the 40th day, they also received $5 \mathrm{~g} / \mathrm{kg}$ of A. septentrionalis leaves (Silva et al. 2016). Group 3 was composed of goats from areas without the occurrence of $A$. septentrionalis. These animals did not receive the leaves of the plant or solutions containing the bacteria.

From the first day after the end of the oral administration of the bacteria (day 41) to the 101st day of experiment, the goats of the three groups were released to graze on a one-hectare paddock whose vegetation was characteristic of the caatinga biome, with a large amount of $A$. septentrionalis (Fig.1A). During these 60 days of field resistance evaluation, each goat received the equivalent of $200 \mathrm{~g}$ of corn kernels, and water and mineral salt ad libitum. For 40 minutes, twice a day, using a binocular, the goats were 
observed for spontaneous consumption of A. septentrionalis leaves and the presence of clinical signs of MFA poisoning.

Goats that died spontaneously were necropsied and samples of organs from the abdominal and thoracic cavities and central nervous system were collected, fixed in $10 \%$ formaldehyde, processed according to routine methods, stained with hematoxylin-eosin (HE) and evaluated histopathologically.

For the statistical analysis the data were expressed as mean and standard deviation and submitted to analysis of distribution of values (normality) using the Shapiro-Wilk test. The comparison between the values obtained in the groups was performed by analysis of variance (Test F) and Tukey test for day of death of the goats (Sampaio 1998). The program IBM SPSS Statistics 23.0 was used for execution of the statistical calculations and the level of significance was $5 \%$.

\section{RESULTS}

The weather in the region where the experiment was carried out is tropical, with rain in the fall and winter. The rainy season begins in February/March and may extend through
August. Temperatures vary following the rainy season, and the annual average is around $24^{\circ} \mathrm{C}$. Although the weather is tropical, the vegetation is formed mainly by hypoxerophilic caatinga, but with areas of deciduous and semi-deciduous forest, this is because the municipality of Limoeiro is in the transition region between the semi-arid and tropical weather.

In the first 15 days of observation of the field resistance test, it was verified that the goats from the three groups only tasted the green leaves of Amorimia septentrionalis, not having predilection for the consumption of this plant. The main species consumed by goats from all groups were mainly Cnidoscolus phyllacanthus (favela), Poincianella pyramidalis (catingueira), Hypolytrum pungens (capim navalha), Ipomoea bahiensis (jetirana), Mimosa tenuiflora (jurema preta), Croton heliotropiifolius (velame), Melochia tomentosa L (capa bode), vagens de Prosopis juliflora (algaroba), Aspidosperma pyrifolium Mart. (pereiro) and Bromelia laciniosa (macambira).

From the 16 th to the 22 nd day of the experiment, it was observed that goats from all groups began to ingest more
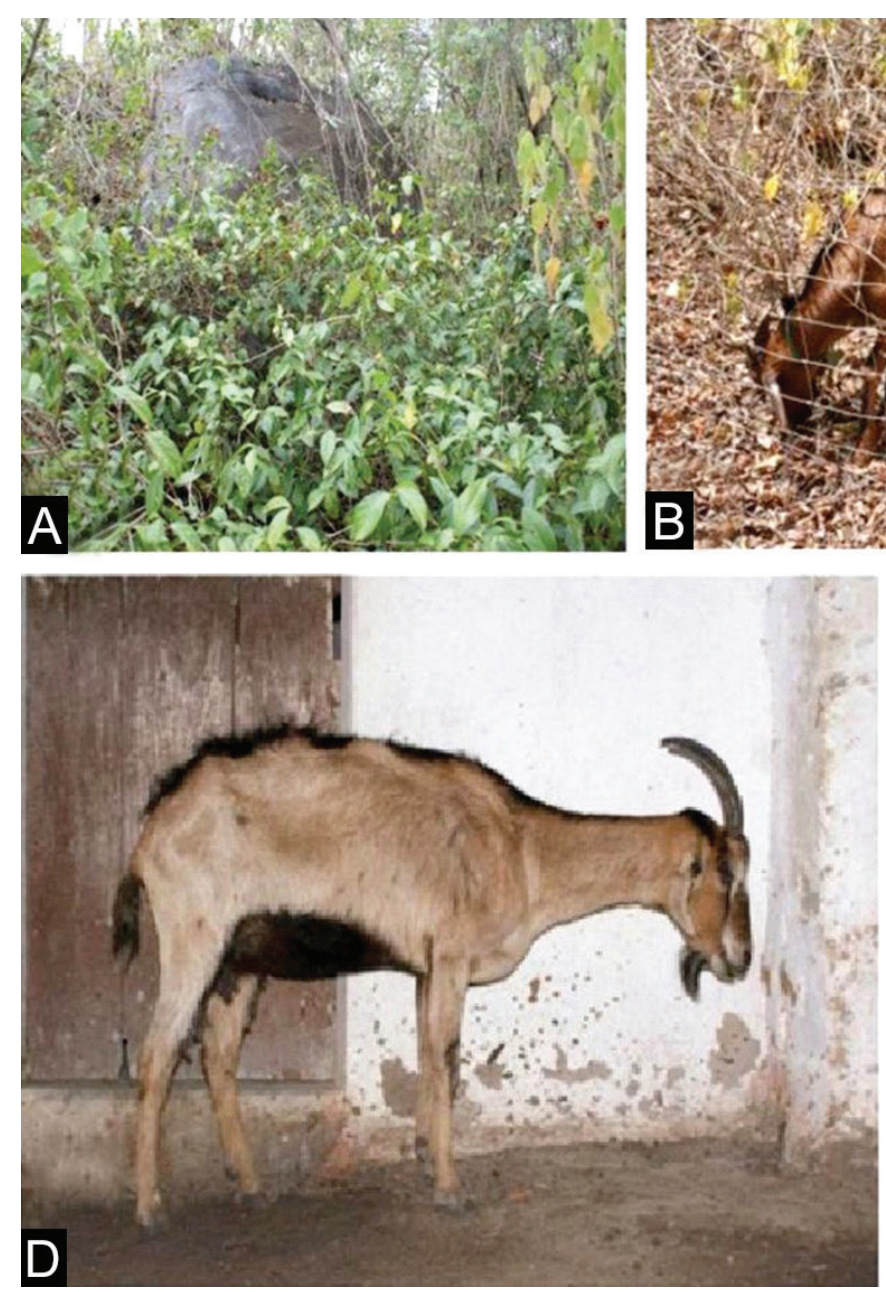
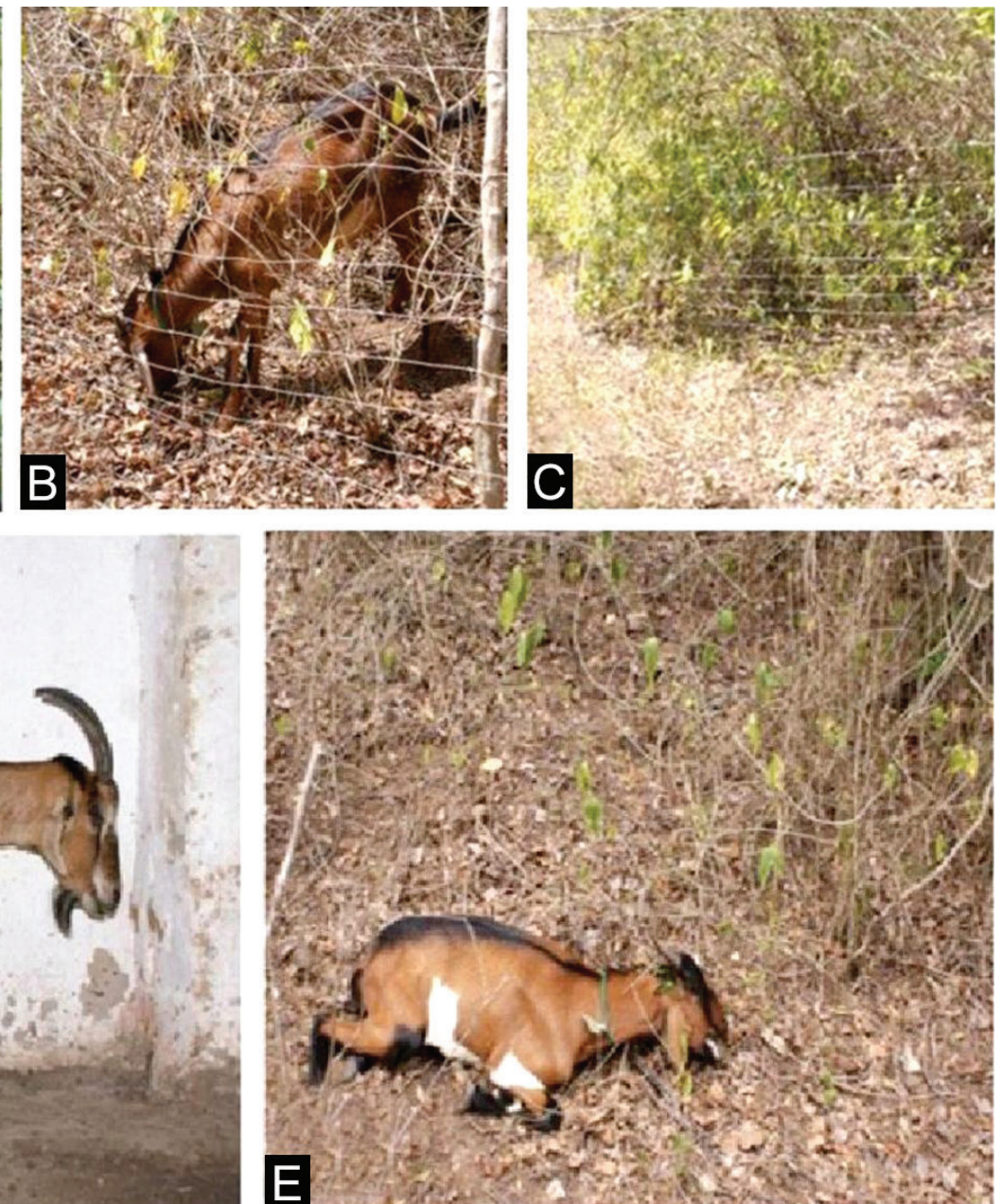

Fig.1. (A) Area with large amount of Amorimia septentrionalis in the location where the experiment was carried out (Limoeiro/PE). (B) Caprine spontaneously ingesting the leaves of $A$. septentrionalis 16 days after the start of the experiment. (C) Predominance of $A$. septentrionalis in comparison with other plants. (D) Caprine from Group 3 presenting extended neck and engorged jugular after natural ingestion of A. septentrionalis. (E) Caprine from Group 2 showing clinical signs of intoxication, which evolved to death 57 days after the natural ingestion of $A$. septentrionalis. 
frequently both green leaves and dry leaves fallen onto the ground of $A$. septentrionalis (Fig.1B), but still in small amounts (between two and five mouthfuls) per animal. However, no clinical signs of poisoning were observed in the goats. From the 25 th to the 27 th days of the experiment, there was already a scarcity of vegetation, but there were still $A$. septentrionalis (Fig.1C). During this period all goats from the three groups were seen ingesting $A$. septentrionalis. Four goats from Group 3 were found dead (Table 1) and two presented clinical signs of MFA poisoning that consisted mainly of extended head and neck, engorged jugular vein and inability to stand up, being withdrawn from the experiment due to the risk of death (Fig.1D). At necropsy and microscopic examination, no significant changes were observed.

There were no clinical signs of poisoning in Group 1 and Group 2 until the 40th day of the experiment and during that period it was observed that there was consumption of A. septentrionalis leaves. From the 41st to the 60th days of observation, in December 2014 and January 2015, there were still rainfall in the Municipality (Fig.2). By the 52nd day it was possible to identify several specimens of $A$. septentrionalis in bud stage and it was noted that many had been consumed by caprine from Group 1 and Group 2. From the 55th to the 60th days of observation (Table 1), all goats in Group 2 presented severe clinical signs of poisoning consisting of constant bleating, inability to stand up, jugular engorgement and extended neck, evolving to death (Fig.1E). During this same period, more discrete clinical signs were observed in two goats from Group 1, however, they also died. The other four goats of Group 1 were found dead from the 56th to the 60th day of observation (Table 1) without showing any clinical signs of poisoning. In only one goat can be observed macroscopic lesions that consisted mainly of consolidation of cranial lung lobes with presence of whitish coalescing areas interspersed with areas of congestion. Histologically, in the pulmonary parenchyma, there was congestion, edema and severe inflammatory infiltrate of mono and polymorphonuclear cells. In the kidneys, there was no hydropic degeneration of the epithelium of the contorted renal tubules.
The goats from Group 3 died on average $25.5 \pm 0.9$ days after the start of the experiment, a significantly lower result $(\mathrm{p}<0.05)$ than Group 1 (58.6 \pm 1.3 days) and Group 2 (57.8 \pm 1.5 days) (Table 2$)$.

Table 1. Period from the beginning of exposure to natural poisoning by Amorimia septentrionalis in goats inoculated with sodium monofluoroacetate degrading bacteria (Group 1 and 2) and control goats (Group 3) until clinical signs of poisoning or death

\begin{tabular}{|c|c|c|}
\hline Group/Goat & Clinical signs (day) & Day of death \\
\hline \multicolumn{3}{|l|}{ Group 1} \\
\hline Goat 1 & 55 th & 57 th \\
\hline Goat 2 & 57 th & 59 th \\
\hline Goat 3 & - & 56th \\
\hline Goat 4 & - & 57 th \\
\hline Goat 5 & - & 60th \\
\hline Goat 6 & - & 60th \\
\hline \multicolumn{3}{|l|}{ Group 2} \\
\hline Goat 7 & 55 th & 57 th \\
\hline Goat 8 & 56 th & 56 th \\
\hline Goat 9 & 57 th & 57 th \\
\hline Goat 10 & 56 th & 58th \\
\hline Goat 11 & 58 th & 59th \\
\hline Goat 12 & 59th & 60th \\
\hline \multicolumn{3}{|l|}{ Group 3} \\
\hline Goat 13 & - & 25 th \\
\hline Goat 14 & - & 25 th \\
\hline Goat 15 & - & 26th \\
\hline Goat 16 & - & 27 th \\
\hline Goat $17^{\mathrm{a}}$ & 25 th & - \\
\hline Goat $18^{a}$ & 26th & - \\
\hline
\end{tabular}

${ }^{\mathrm{a}}$ Goat 17 and 18 was withdrawn on the 25th and 26th day respectively from the experiment due to the risk of death.

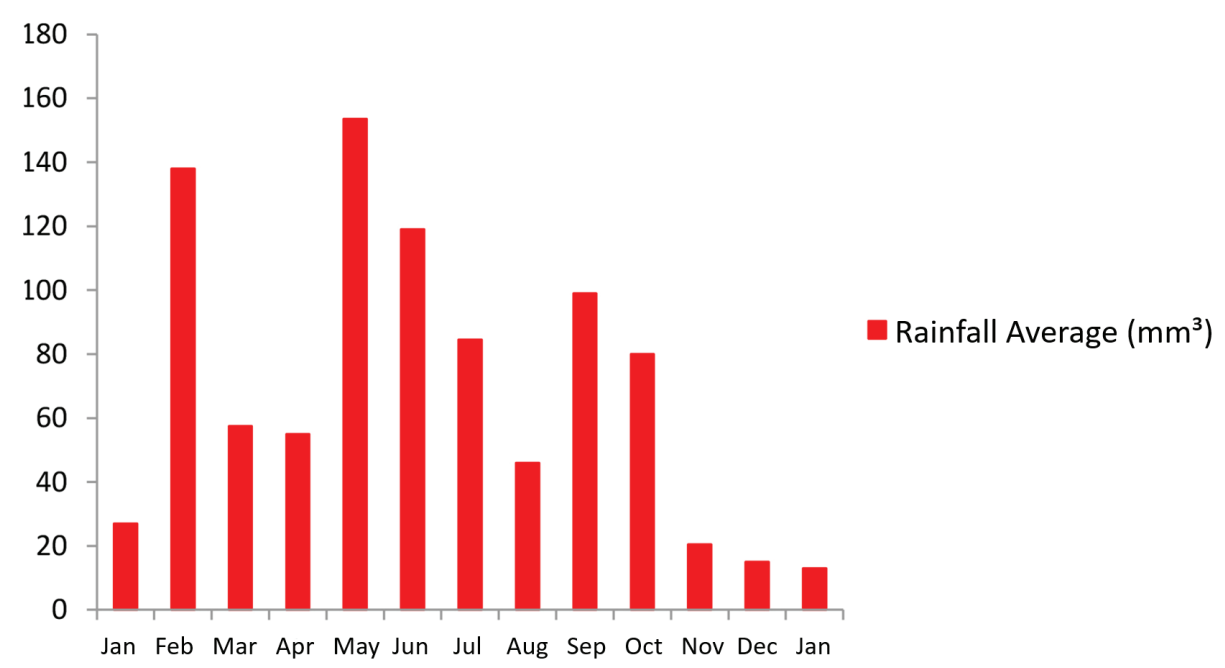

Fig.2. Graphic representing the rainfall in the city of Limoeiro/PE during the entire year of 2014 until January 2015. 
Table 2. Mean and standard deviation of the period from beginning of the exposure to natural poisoning by Amorimia septentrionalis in goats inoculated with sodium monofluoroacetate degrading bacteria (Group 1 and 2) and control goats (Group 3) until death of the animals

\begin{tabular}{cc}
\hline Groups & Day of death* \\
\hline $1(\mathrm{n}=6)$ & $58.6 \pm 1.3^{\mathrm{a}}$ \\
$2(\mathrm{n}=6)$ & $57.8 \pm 1.5^{\mathrm{a}}$ \\
$3(\mathrm{n}=4)$ & $25.5 \pm 0.9^{\mathrm{b}}$
\end{tabular}

$\mathrm{n}=$ Number of goats; ${ }^{*}$ Tukey's test; ${ }^{\mathrm{a}, \mathrm{b}}$ different letters in the same column indicate statistical difference $(\mathrm{p}<0.05)$ between groups.

\section{DISCUSSION}

The results of the present study demonstrate that goats that received oral MFA-degrading bacteria isolated from the soil and plants containing MFA, when exposed to the ingestion of the plant naturally, take longer to develop clinical signs of poisoning or to die when compared to animals who did not receive these bacteria. Similar results were obtained by Pessoa et al. (2015) and Silva et al. (2015) in experiments where the plant was administered experimentally in known amounts and after the final period of ingestion of the bacteria. In another experiment, Silva et al. (2016) continued to administer MFA-degrading bacteria daily at the same time as they performed administration of Amorimia septentrionalis and demonstrated that the continuous and simultaneous administration of the bacteria and $A$. septentrionalis conferred resistance to poisoning. These results also reinforce the hypothesis that the administration of the bacterium should be continuous and simultaneous to the administration of the plant (Silva et al. 2016), which was not performed in the present study.

Another factor to be considered is that the goats that received the bacteria only got intoxicated when they ate the plant in the budding phase, soon after scarce rains (Fig.2). In this phase the plant is considered more toxic, i.e., it has a higher MFA concentration (Tokarnia et al. 2012, Lee et al. 2012), which possibly facilitated poisoning, since the bacteria that could still be in the rumen of the animals were not able to degrade larger amounts of MFA.

Further studies should be performed with the aim of quantifying and determining how long these bacteria stay viable in the animals' rumen, since it can be observed that when the administration of it is interrupted, the resistance is not permanent.

\section{CONCLUSION}

Goats that simultaneously received, orally, degrading bacteria of sodium monofluoroacetate (Ralstonia sp. and Burkholderia sp.; Paenibacillus sp. and Cupriavidus sp.) presented higher resistance to the natural poisoning by Amorimia septentrionalis.

Acknowledgments.- This work was funded by the National Institute of Science and Technology (INCT) for the Control of Plant Intoxications (Proc. CNPq 573534 / 2008-0).

\section{REFERÊNCIAS}

Barbosa J.D., Oliveira C.M.C., Tokarnia C.H. \& Riet-correa F. 2003. Comparação da sensibilidade de bovinos e búfalos à intoxicação por Palicourea marcgravii (Rubiaceae). Pesq. Vet. Bras. 23(4):167-172. <http://dx.doi.org/10.1590/ S0100-736X2003000400005>

Brito L.B., Albuquerque R.F., Rocha B.P., Albuquerque S.S., Lee S.T., Medeiros R.M.T., Riet-Correa F. \& Mendonça F.S. 2016. Spontaneous and experimental poisoning of cattle by Palicourea aeneofusca in the region of Pernambuco and induction of conditioned food aversion. Ciência Rural 46(1):138-143. <http://dx.doi.org/10.1590/0103-8478cr20150079>

Camboim E.K.A., Tadra-Sfeir M.Z., Souza E.M., Pedrosa F.O., Andrade P.P., McSweeney C.S., Riet-Correa F. \& Melo M.A. 2012. Defluorination of sodium fluoroacetate by bacteria from soil and plants in Brazil. Scient. World J. 2012:149893. <http://dx.doi.org/10.1100/2012/149893> <PMid:22619595>

Duarte A.L.L., Medeiros R.M.T., Carvalho F.K.L., Lee S.T., Cook D., Pfister J.A., Costa V.M.M. \& Riet-Correa F. 2014. Induction and transfer of resistance to poisoning by Amorimia (Mascagnia) septentrionalis in goats. J. Appl. Toxicol. 34(2):220-223. <http://dx.doi.org/10.1002/jat.2860><PMid:23400835>

Fetzner S. \& Lingens F. 1994. Bacterial dehalogenases: biochemistry, genetics, and biotechnological applications. Microbiol. Revs 58(4):641685. <PMid:7854251>

Lee S.T., Cook D., Riet-Correa F., Pfister J.A., Anderson W.R., Lima F.G. \& Gardner D.R. 2012. Detection of monofluoroacetate in Palicourea and Amorimia species. Toxicon 60(5):791-796. <http://dx.doi.org/10.1016/j. toxicon.2012.05.029><PMid:22699106>

Nogueira V.A., França T.N., Peixoto T.C., Caldas S.A., Armién A.G. \& Peixoto P.V. 2010. Intoxicação experimental por monofluoroacetato de sódio em bovinos: aspectos clínicos e patológicos. Pesq. Vet. Bras. 30(7):533-540. <http://dx.doi.org/10.1590/S0100-736X2010000700004>

Pessoa C.R.M., Medeiros R.M.T. \& Riet-Correa F. 2013. Importância econômica, epidemiologia e controle das intoxicações por plantas no Brasil. Pesq. Vet. Bras. 33(6):752-758. <http://dx.doi.org/10.1590/S0100-736X2013000600011>

Pessoa D.A.N., Silva L.C.A., Lopes J.R.G., Macêdo M.M.S., Garino Junior F., Azevedo S.S. \& Riet-Correa F. 2015. Resistência à intoxicação por Amorimia septentrionalis em caprinos, induzida pela inoculação ruminal das bactérias Pigmentiphaga kullae e Ancylobacter dichloromethanicus. Pesq. Vet. Bras. 35(2):125-128. <http://dx.doi.org/10.1590/S0100-736X2015000200005>

Sampaio I.B.M. 1998. Estatística Aplicada à Experimentação Animal. Fundação de Ensino e Pesquisa em Medicina Veterinária e Zootecnia, Belo Horizonte. 221p.

Silva L.C.A., Pessoa D.A.N., Lopes J.R.G., Silva L.S.A., Albuquerque L.G., Medeiros R.M.T., Garino Junior F. \& Riet-Correa F. 2015. Transferência da resistência à intoxicação por Amorimia septentrionalis em caprinos mediante transfaunação de conteúdo ruminal proveniente de caprinos inoculados com bactérias degradadoras de monofluoroacetato de sódio. Ciência Rural 45(12):2218-2222. <http://dx.doi.org/10.1590/0103-8478cr20141231>

Silva L.C.A., Pessoa D.A.N., Lopes J.R.G., Albuquerque L.G., Silva L.S.A., Garino Junior F.G. \& Riet-Correa F. 2016. Protection against Amorimia septentrionalis poisoning in goats by the continuous administration of sodium monofluoroacetate-degrading bactéria. Toxicon 111:65-68. <http://dx.doi.org/10.1016/j.toxicon.2015.12.016><PMid:26747472>

Tokarnia C.H., Brito M.F., Barbosa J.D., Peixoto P.V. \& Döbereiner J. 2012. Plantas Tóxicas do Brasil para Animais de Produção. $2^{\text {a }}$ ed. Helianthus, Rio de Janeiro, p.55-90. 